\section{Response of Diverse Lettuce Types to Fertilizer Phosphorus}

\author{
C.A. Sanchez \\ Yuma Agricultural Research Center, University of Arizona, 6425 West 8th \\ Street, Yuma, AZ 85364
}

N.M. El-Hout

South Bay Growers, P.O. Drawer A, South Bay, FL 33493

Additional index words. Lactuca sativa, soil test, Bibb, Boston, leaf lettuce, romaine, organic soils

\begin{abstract}
Four field experiments were conducted from 1990 to 1992 on Histosols in southern Florida to compare the relative response of various types of lettuce (Lactuca sativa L.) (i.e., leaf, Boston, Bibb, romaine, and crisphead lettuce) to $P$ fertilization. All lettuce types showed large yield and quality responses to $P$ fertilization. Because environmental conditions affected yield potential, $P$ rates required for optimal yield varied for lettuce types across experiments. However, with the exception of Boston, the $P$ rates required for optimal yield were similar when averaged over all experiments. Furthermore, the relationship between relative yield and soil-test $\mathbf{P}$ across all seasons showed that a similar soil-test $P$ index level was required for maximum yield of all lettuce types. Overall, the results of this study suggest that existing soil-test-based fertilizer recommendations for crisphead lettuce are adequate for other lettuce types currently grown.
\end{abstract}

About 80,000 ha of lettuce is produced in the United States annually. Although most of this lettuce is the crisphead type, hectarage of other lettuce types has increased due to an expanding consumer demand. Leaf, butter, and romaine (cos) types are grown widely in the eastern and western United States. Of the butter types, Bibb and Boston are grown.

There is large variability in biomass production, morphological traits, and nutrient uptake by the various lettuce types. For example, leaf, Boston, Bibb, and romaine do not produce tight compact heads, as does crisphead lettuce. Additionally, leaf, Boston, and Bibb generally produce appreciably less biomass and, therefore, tend to accumulate lower amounts of nutrients than romaine and crisphead types.

The production of high-quality lettuce is highly dependent on soil fertility. Lettuce typically shows large yield and quality responses to fertilizer P (Alt, 1987; Greenwood et al., 1980; Sanchez et al., 1990). Phosphorus fertilizer recommendations for lettuce grown on organic soils in southern Florida are based on a water-extractable P soil test (Sanchez, 1990). However, these recommendations are based primarily on soil-test-calibration research conducted with the crisphead type. Limited infor-

Received for publication 12 Sept. 1994. Accepted for publication 27 Jan. 1995. This research was funded in part by the Southern Florida Soil Test Advisory Board. The cost of publishing this paper was defrayed in part by the payment of page charges. Under postal regulations, this paper therefore must be hereby marked advertisement solely to indicate this fact. experiments. because of different harvest date. propriate for various planting dates; and recorded harvest dates and weather conditions (Table 1). Spring 1990 and Fall 1991 experiments were conducted on a Pahokee muck (euic hyperthermic Lithic Medisaprist); Fall 1990 and Winter 1991 experiments were conducted on a Terra Ceia muck (euic hyperthermic Typic Medisaprist). We selected sites that tested low in available P. Water-extractable P values before fertilization were (in $\mathrm{g} \cdot \mathrm{m}^{-3}$ ) 0.5 in Spring 1990, 4.0 in Fall 1990, 2.9 in Fall 1991, and 4.4 in Winter 1991. Soil on all sites was calcareous with $\mathrm{pH}$ values ranging from 6.7 to 7.3 .

Phosphorus rates were $0,50,100,200$, and $300 \mathrm{~kg} \mathrm{P} / \mathrm{ha}$ in all experiments, using triple superphosphate. Each experiment used a splitplot arrangement in a randomized completeblock design with four replications in Spring 1990 and five replications in all other experiments. Phosphorus treatments were the main plots and lettuce types the subplots. The main plots measured $8.1 \mathrm{~m}$ wide (nine beds $0.9 \mathrm{~m}$ wide $\times 15.2 \mathrm{~m}$ long). The center five beds of the plot area contained the five lettuce types and were bordered on each side by two beds of crisphead lettuce.

All fertilization, other than $P$, were standard practices. The micronutrients $\mathrm{Zn}, \mathrm{Mn}$, and $\mathrm{B}$ were applied at 9, 9, and $2 \mathrm{~kg} \cdot \mathrm{ha}^{-1}$, respectively. Potassium was applied as $\mathrm{KCl}$ based on preplant soil tests (Sanchez, 1990). Phosphorus, K, and micronutrients were broadcast-applied and disked into the soil before planting. Nitrogen was applied at $50 \mathrm{~kg} \cdot \mathrm{ha}^{-1}$ as a sidedress at the eight-leaf stage. Water was supplied using subsurface irrigation by attempting to maintain a water table $\approx 60 \mathrm{~cm}$ below the soil surface (Snyder et al., 1978).

Lettuce was seeded in elevated double-row beds on 0.9-m centers and thinned at the fourleaf stage to a $25-\mathrm{cm}$ intrarow spacing to give a plant population of $\approx 60,000$ plants/ha. At maturity, heads of each lettuce type were har-

Table 1. Lettuce type, cultivar, planting date, harvest date, and weather conditions across $\mathrm{P}$ fertilizer field

\begin{tabular}{|c|c|c|c|c|c|c|c|}
\hline \multirow[b]{2}{*}{ Experiment } & \multicolumn{2}{|c|}{ Lettuce } & \multicolumn{2}{|c|}{ Date } & \multirow{2}{*}{$\begin{array}{l}\text { Mean } \\
\text { temp } \\
\left({ }^{\circ} \mathrm{C}\right)\end{array}$} & \multirow{2}{*}{$\begin{array}{c}\text { Rainfall } \\
(\mathrm{mm})^{\mathrm{z}}\end{array}$} & \multirow{2}{*}{$\begin{array}{c}\text { Pan } \\
\text { evaporation } \\
(\mathrm{mm})^{\mathrm{z}} \\
\end{array}$} \\
\hline & Type & Cultivar & Planting & Harvest & & & \\
\hline \multirow[t]{5}{*}{ Spring 1990} & Leaf & Royal Green & 28 Feb. & 23 Apr. & 20.8 & 44 & 278 \\
\hline & Bibb & Floribibb & 28 Feb. & 27 Apr. & 20.9 & 44 & 305 \\
\hline & Boston & Genecorp Boston & 28 Feb. & 27 Apr. & 20.9 & 44 & 305 \\
\hline & Romaine & Tall Guzman & 28 Feb. & 2 May & 21.1 & 82 & 333 \\
\hline & Crisphead & South Bay & 28 Feb. & 2 May & 21.1 & 82 & 333 \\
\hline \multirow[t]{5}{*}{ Fall 1990} & Leaf & Royal Green & 29 Nov. & 2 Feb. & 20.2 & 241 & 192 \\
\hline & Bibb & Floribibb & 29 Nov. & 2 Feb. & 20.2 & 241 & 192 \\
\hline & Boston & Genecorp Boston & 29 Nov. & 2 Feb. & 20.2 & 241 & 192 \\
\hline & Romaine & Tall Guzman & 29 Nov. & 7 Feb. & 20.2 & 241 & 212 \\
\hline & Crisphead & South Bay & 29 Nov. & 7 Feb. & 20.2 & 241 & 212 \\
\hline \multirow[t]{5}{*}{ Fall 1991} & Leaf & Royal Green & 15 Nov. & 9 Jan. & 19.1 & 68 & 153 \\
\hline & Bibb & Floribibb & 15 Nov. & 9 Jan. & 19.1 & 68 & 153 \\
\hline & Boston & Genecorp Boston & 15 Nov. & 9 Jan. & 19.1 & 68 & 153 \\
\hline & Romaine & Augustus & 15 Nov. & 15 Jan. & 19.6 & 78 & 173 \\
\hline & Crisphead & Raleigh & 15 Nov. & 24 Jan. & 18.9 & 89 & 193 \\
\hline \multirow[t]{5}{*}{ Winter 1991} & Leaf & Royal Green & 3 Dec. & 31 Jan. & 17.6 & 40 & 155 \\
\hline & Bibb & Floribibb & 3 Dec. & 31 Jan. & 17.6 & 40 & 155 \\
\hline & Boston & $70291 \mathrm{MT}$ & 3 Dec. & 1 Feb. & 17.6 & 40 & 160 \\
\hline & Romaine & Tall Guzman & 3 Dec. & 11 Feb. & 17.4 & 76 & 190 \\
\hline & Crisphead & Raleigh & 3 Dec. & 11 Feb. & 17.4 & 76 & 190 \\
\hline
\end{tabular}

${ }^{2}$ Differences in pan evaporation, and sometimes rainfall, among lettuce types within season occurred 
vested from $6 \mathrm{~m}$ of each of two rows per bed. Marketable yields were determined after grading according to standard marketing criteria. In all experiments, lettuce plants were collected for $\mathrm{P}$ analysis from each plot at maturity. The oldest sound leaf from each of 10 plants was collected in each plot at the eightleaf stage in Fall 1991 and Winter 1991. Plant material was dried at $60 \mathrm{C}$ for $48 \mathrm{~h}$. After wetashing, $\mathrm{P}$ was determined colorimetrically (Wolf, 1982). Soil samples were taken at random within the lettuce beds to a depth of $15 \mathrm{~cm}$ $\approx 30$ to 40 days after fertilizer application. These samples were analyzed for water-soluble P using Murphy and Riley's (1962) method after a 1 soil : 12.5 water (v/v) extraction (Sanchez, 1990). Because of weather conditions, we were not able to take soil samples during Spring 1990. The soil test information was used to estimate critical soil test values required for optimal yield of each lettuce type.

Data were subjected to analysis of variance using the SAS general linear model, and response models were evaluated using the SAS general linear model and SAS-Nonlinear routine (SAS Institute, 1982). Several models were evaluated, including the polynomial linear and quadratic, linear response and plateau, and quadratic response and plateau. Model selection was based on the coefficient of determination and a visual inspection of the residuals.

\section{Results and Discussion}

Marketable yields ranged from (in $\mathrm{Mg}_{\mathrm{h}} \mathrm{ha}^{-1}$ ) 17.7 to 30.6 for leaf, 11.2 to 18.7 for Bibb, 7.4 to 18.7 for Boston, 23.5 to 47.6 for romaine, and 18.6 to 52.1 for crisphead lettuce. Although we selected cultivars considered appropriate for each season, there were strong environmental interactions with marketable yields of all lettuce types. Warm weather during the latter part of the growing season in Spring 1990 limited yields for crisphead lettuce. During Fall 1990, a 140-mm rainfall on $15 \mathrm{Jan}$. flooded the field for $\approx 24 \mathrm{~h}$. This flooding of the root zone seemed to have the greatest negative impact on Boston, romaine, and crisphead lettuce types. Growing conditions encountered during Fall 1991 and Winter 1991 were generally favorable for the production of all lettuce types.

Applying $\mathrm{P}$ during all experiments significantly increased lettuce yield, tissue $P$ concentration, and aboveground $\mathrm{P}$ accumulation (Tables 2-5). Because there were significant $P$ rate $\times$ lettuce type interactions, yield response equations to $\mathrm{P}$ for each lettuce type were determined (Table 2). An illustration of the observed and predicted response among lettuce types is shown for Fall 1991 in Fig. 1.

Interestingly, the relative yield response of lettuce types to $\mathrm{P}$ varied by experiment (Table 2). For example, in Spring 1990 Bibb and crisphead showed a lesser response to $P$ than did leaf, Boston, and romaine. However, Bibb and crisphead lettuce showed the greatest response to P in Fall 1990, but Bibb did in Fall 1991.

An evaluation of aboveground whole-plant
$\mathrm{P}$ concentration and $\mathrm{P}$ accumulation data in our experiments offers limited interpretive insight concerning the variable yield response (Tables 3 and 5; Fig. 2). Generally, leaf, Boston, Bibb, and romaine tended to have higher Pconcentrations in mature heads than crisphead

lettuce (Table 3). A notable exception was in Spring 1990, when crisphead performed poorly relative to the other lettuce types grown during the same period. Although $P$ concentrations in the mature plants of leaf, Boston, Bibb, and romaine were generally higher than those of

Table 2. Summary of equation parameters for relationships between marketable yield and fertilizer $\mathrm{P}$ for the various lettuce types across four field experiments.

\begin{tabular}{|c|c|c|c|c|c|c|c|c|}
\hline \multirow[b]{2}{*}{ Experiment } & \multirow{2}{*}{$\begin{array}{l}\text { Lettuce } \\
\text { type }\end{array}$} & \multirow{2}{*}{$\begin{array}{c}\text { Model } \\
\text { selected }^{z}\end{array}$} & \multicolumn{4}{|c|}{ Equation parameters } & \multirow{2}{*}{$\begin{array}{l}\text { P rate for } \\
\text { max. yield } \\
\left(\mathrm{kg} \cdot \mathrm{ha}^{-1}\right)\end{array}$} & \multirow{2}{*}{ 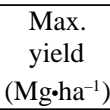 } \\
\hline & & & A & $\mathrm{B}$ & $\mathrm{C}$ & $r^{2}$ & & \\
\hline \multirow[t]{5}{*}{ Spring 1990} & Leaf & Quad & 15.49 & 0.089 & -0.00013 & 0.83 & 300 & 30.6 \\
\hline & Bibb & QRP & 13.00 & 0.154 & -0.00104 & 0.46 & 74 & 18.7 \\
\hline & Boston & Quad & 14.75 & 0.048 & -0.00006 & 0.66 & 300 & 23.3 \\
\hline & Romaine & Quad & 27.82 & 0.094 & -0.00015 & 0.66 & 300 & 42.7 \\
\hline & Crisphead & QRP & 19.84 & 0.297 & -0.00131 & 0.65 & 113 & 36.7 \\
\hline \multirow[t]{5}{*}{ Fall 1990} & Leaf & QRP & 9.96 & 0.085 & -0.00026 & 0.46 & 160 & 16.7 \\
\hline & Bibb & Quad & 8.19 & 0.054 & -0.00014 & 0.52 & 195 & 12.5 \\
\hline & Boston & Quad & 2.75 & 0.0122 & 0.00002 & 0.78 & 300 & 7.41 \\
\hline & Romaine & QRP & 1.75 & 0.619 & -0.00441 & 0.69 & 70 & 23.5 \\
\hline & Crisphead & Quad & 4.47 & 0.053 & -0.00002 & 0.75 & 300 & 18.6 \\
\hline \multirow[t]{5}{*}{ Fall 1991} & Leaf & QRP & 10.50 & 0.339 & -0.00401 & 0.75 & 42 & 17.7 \\
\hline & $\mathrm{Bibb}$ & QRP & 5.31 & 0.088 & -0.00033 & 0.69 & 133 & 11.2 \\
\hline & Boston & QRP & 2.73 & 0.297 & -0.00159 & 0.91 & 93 & 16.6 \\
\hline & Romaine & QRP & 13.23 & 0.694 & -0.00367 & 0.66 & 94 & 45.9 \\
\hline & Crisphead & QRP & 27.53 & 0.639 & -0.00415 & 0.73 & 77 & 52.1 \\
\hline \multirow[t]{5}{*}{ Winter 1991} & Leaf & QRP & 4.42 & 0.355 & -0.00195 & 0.74 & 91 & 20.6 \\
\hline & Bibb & QRP & 2.28 & 0.146 & -0.00044 & 0.83 & 165 & 14.4 \\
\hline & Boston & QRP & 2.35 & 0.213 & -0.00090 & 0.88 & 118 & 14.9 \\
\hline & Romaine & QRP & 21.21 & 0.471 & -0.0021 & 0.68 & 112 & 47.6 \\
\hline & Crisphead & QRP & 2.63 & 0.884 & -0.00451 & 0.91 & 98 & 46.0 \\
\hline
\end{tabular}

${ }^{2} \mathrm{Quad}=$ polynomial quadratic $(\mathrm{Y}=\mathrm{A}+\mathrm{bx}+\mathrm{Cx} 2) ; \mathrm{QRP}=$ quadratic response and plateau model $(\mathrm{Y}=\mathrm{A}+$ $\mathrm{Bx}+\mathrm{Cx}^{2}$ if $\mathrm{x}<\mathrm{Cp}$ or $\mathrm{Y}=\mathrm{Yp}$ if $\mathrm{x} \geq \mathrm{Cp}$ ). $\mathrm{Y}$ is marketable yield (megatons per hectare), $\mathrm{x}$ is $\mathrm{P}$ rate (kilogram per hectare); A (intercept), B (linear coefficient), C (quadratic coefficient), Cp (critical rate of fertilization, which occurs at the intersection of the quadratic response and the plateau lines), and Yp (plateau yield) are constants obtained by fitting the model to the data.

Table 3. Phosphorus concentration in aboveground whole plant at maturity for five lettuce types in four experiments.

\begin{tabular}{|c|c|c|c|c|c|}
\hline \multirow{3}{*}{$\begin{array}{l}\text { P rate } \\
\left(\mathrm{kg} \cdot \mathrm{ha}^{-1}\right)\end{array}$} & \multicolumn{5}{|c|}{$\mathrm{P}$ concn $\left(\mathrm{g} \cdot \mathrm{kg}^{-1}\right)$} \\
\hline & \multicolumn{5}{|c|}{ Lettuce type } \\
\hline & Leaf & Bibb & Boston & Romaine & Crisphead \\
\hline \multicolumn{6}{|c|}{ Spring 1990} \\
\hline 0 & 3.6 & 7.4 & 5.2 & 5.9 & 5.9 \\
\hline 50 & 4.4 & 9.7 & 6.4 & 7.6 & 6.7 \\
\hline 100 & 3.5 & 9.7 & 5.8 & 6.4 & 6.1 \\
\hline 200 & 4.6 & 8.7 & 6.8 & 8.1 & 6.7 \\
\hline 300 & 5.4 & 11.3 & 8.5 & 7.1 & 6.4 \\
\hline Statistic & $\mathrm{L}^{* *}$ & $\mathrm{~L}^{*}$ & $\mathrm{~L}^{* *}$ & $\mathrm{NS}^{\mathrm{z}}$ & $\mathrm{NS}^{\mathrm{z}}$ \\
\hline \multicolumn{6}{|c|}{ Fall 1990} \\
\hline 0 & 5.6 & 6.7 & 6.5 & 5.2 & 3.7 \\
\hline 50 & 6.8 & 7.1 & 6.1 & 6.5 & 5.4 \\
\hline 100 & 8.3 & 8.7 & 6.6 & 6.7 & 5.8 \\
\hline 200 & 9.1 & 8.9 & 8.0 & 7.9 & 6.6 \\
\hline 300 & 9.4 & 10.9 & 9.7 & 9.7 & 7.1 \\
\hline Statistic & $\mathrm{L}^{* * * *}, \mathrm{Q}^{*}$ & $\mathrm{NS}^{\mathrm{z}}$ & $\mathrm{L}^{* * * *}, \mathrm{Q}^{*}$ & $\mathrm{~L}^{* * * *}$ & $\mathrm{~L}^{* * *}, \mathrm{Q}^{*}$ \\
\hline \multicolumn{6}{|c|}{ Fall 1991} \\
\hline 0 & 6.7 & 6.7 & 7.0 & 4.6 & 5.3 \\
\hline 50 & 8.6 & 7.9 & 8.9 & 6.8 & 6.8 \\
\hline 100 & 9.6 & 9.0 & 9.9 & 6.6 & 7.1 \\
\hline 200 & 9.7 & 9.2 & 10.6 & 7.9 & 7.5 \\
\hline 300 & 10.8 & 10.0 & 11.1 & 7.9 & 8.3 \\
\hline Statistic & $\mathrm{L}^{* * * *}, \mathrm{Q}^{*}$ & $\mathrm{~L}^{* * * *}, \mathrm{Q}^{*}$ & $\mathrm{~L}^{* * *}, \mathrm{Q}^{* * *}$ & $\mathrm{~L}^{* * *}, \mathrm{Q}^{* * *}$ & $\mathrm{~L}^{* * * *}$ \\
\hline \multicolumn{6}{|c|}{ Winter 1991} \\
\hline 0 & 7.7 & 7.0 & 7.5 & 8.0 & 5.4 \\
\hline 50 & 9.2 & 8.5 & 9.5 & 9.9 & 8.4 \\
\hline 100 & 10.2 & 9.4 & 9.9 & 11.2 & 8.6 \\
\hline 200 & 11.0 & 10.4 & 11.8 & 11.5 & 9.6 \\
\hline 300 & 12.1 & 10.7 & 12.7 & 13.7 & 10.3 \\
\hline Statistic & $\mathrm{L}^{* * * *}, \mathrm{Q}^{*}$ & $\mathrm{~L}^{* * *}, \mathrm{Q}^{*}$ & $\mathrm{~L}^{* * * *}$ & $\mathrm{~L}^{* * * *}$ & $\mathrm{~L}^{* * *}, \mathrm{Q}^{*}$ \\
\hline
\end{tabular}


Table 4. Leaf $\mathrm{P}$ concentration at the eight-leaf stage for five lettuce types as influenced by $\mathrm{P}$ rate during two growing seasons.

\begin{tabular}{|c|c|c|c|c|c|}
\hline \multirow{3}{*}{$\begin{array}{l}\text { P rate } \\
\left({\left.\mathrm{kg} \cdot h a^{-1}\right)}^{2}\right.\end{array}$} & \multicolumn{5}{|c|}{$\mathrm{P}$ concn $\left(\mathrm{g} \cdot \mathrm{kg}^{-1}\right)$} \\
\hline & \multicolumn{5}{|c|}{ Lettuce type } \\
\hline & Leaf & Bibb & Boston & Romaine & Crisphead \\
\hline \multicolumn{6}{|c|}{ Fall 1991} \\
\hline 0 & 6.7 & 5.2 & 4.9 & 4.7 & 3.4 \\
\hline 50 & 8.7 & 5.7 & 6.0 & 6.1 & 4.7 \\
\hline 100 & 8.9 & 6.9 & 6.2 & 7.2 & 5.1 \\
\hline 200 & 9.4 & 7.3 & 6.9 & 7.6 & 5.1 \\
\hline 300 & 9.9 & 8.1 & 7.2 & 8.3 & 5.6 \\
\hline Statistic & $\mathrm{L}^{* *}, \mathrm{Q}^{* *}$ & $\mathrm{~L}^{* *}, \mathrm{Q}^{*}$ & $\mathrm{~L}^{* * *}, \mathrm{Q}^{* *}$ & $\mathrm{~L}^{* * *}, \mathrm{Q}^{* * * *}$ & $\mathrm{~L}^{* * * *}, \mathrm{Q}^{*}$ \\
\hline \multicolumn{6}{|c|}{ Winter 1991} \\
\hline 0 & 6.8 & 5.2 & 7.6 & 4.6 & 4.4 \\
\hline 50 & 8.6 & 7.0 & 8.5 & 6.3 & 6.8 \\
\hline 100 & 9.5 & 7.2 & 9.5 & 7.7 & 7.0 \\
\hline 200 & 10.0 & 8.8 & 10.1 & 8.2 & 7.6 \\
\hline 300 & 10.7 & 8.7 & 10.4 & 8.9 & 8.6 \\
\hline Statistic & $\mathrm{L}^{* * *}, \mathrm{Q}^{* *}$ & $\mathrm{~L}^{* * *}, \mathrm{Q}^{* *}$ & $\mathrm{~L}^{* * *}, \mathrm{Q}^{* *}$ & $\mathrm{~L}^{* * *}, \mathrm{Q}^{* * *}$ & $L^{* * *}, Q^{*}$ \\
\hline
\end{tabular}

${ }^{* * *, * *, *}$ Significant linear $(\mathrm{L})$ or quadratic $(\mathrm{Q})$ trend at $P \leq 0.001,0.01$, and 0.1 , respectively. ss Nonsignificant at $P>0.1$.

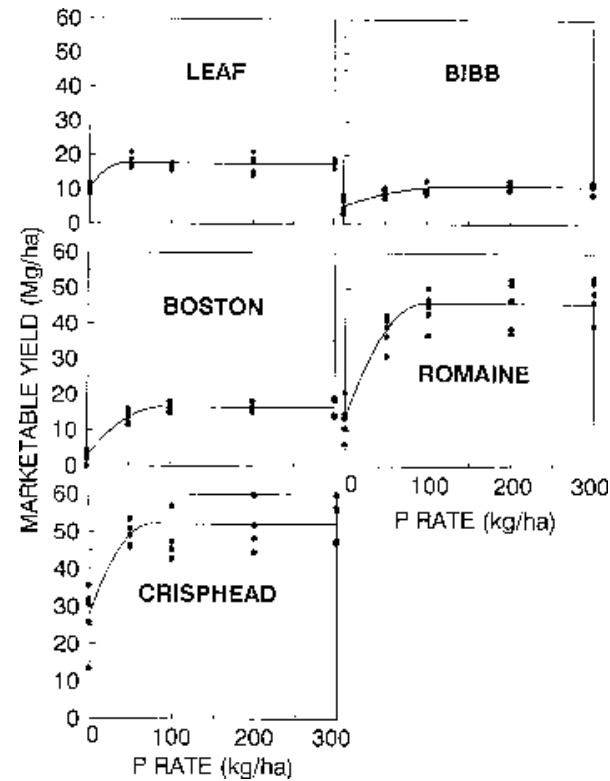

Fig. 1. Observed and predicted yield response of five lettuce types to $\mathrm{P}$ fertilization during Fall 1991.

Table 5. Regression equations describing aboveground $\mathrm{P}$ accumulation by five lettuce types across four seasons.

\begin{tabular}{|c|c|c|c|c|c|}
\hline \multirow[b]{2}{*}{ Experiment } & \multirow[b]{2}{*}{ Lettuce type } & \multicolumn{4}{|c|}{ Equation parameters ${ }^{\mathrm{z}}$} \\
\hline & & $\mathrm{A}$ & $\mathrm{B}$ & $\mathrm{C}$ & $r^{2}$ \\
\hline \multirow[t]{5}{*}{$\overline{\text { Spring } 1990}$} & Leaf & 4.58 & 0.0252 & --- & 0.80 \\
\hline & Bibb & 4.84 & 0.0105 & --- & 0.48 \\
\hline & Boston & 3.31 & 0.0141 & --- & 0.74 \\
\hline & Romaine & 10.66 & 0.0220 & --- & 0.75 \\
\hline & Crisphead & 6.82 & 0.0154 & --- & 0.32 \\
\hline \multirow[t]{5}{*}{ Fall 1990} & Leaf & 2.53 & 0.0302 & -0.00005 & 0.80 \\
\hline & Bibb & 3.23 & 0.0831 & --- & 0.60 \\
\hline & Boston & 1.88 & 0.0110 & --- & 0.84 \\
\hline & Romaine & 4.09 & 0.0221 & --- & 0.77 \\
\hline & Crisphead & 3.68 & 0.0173 & --- & 0.87 \\
\hline \multirow[t]{5}{*}{ Fall 1991} & Leaf & 5.53 & 0.0379 & -0.00008 & 0.57 \\
\hline & Bibb & 3.53 & 0.0245 & -0.00006 & 0.51 \\
\hline & Boston & 4.10 & 0.0278 & -0.00004 & 0.85 \\
\hline & Romaine & 6.36 & 0.0861 & -0.00019 & 0.85 \\
\hline & Crisphead & 10.36 & 0.021 & --- & 0.60 \\
\hline \multirow[t]{5}{*}{ Winter 1991} & Leaf & 6.78 & 0.0540 & -0.00011 & 0.77 \\
\hline & Bibb & 4.09 & 0.0389 & -0.00007 & 0.85 \\
\hline & Boston & 4.75 & 0.04365 & -0.00008 & 0.70 \\
\hline & Romaine & 14.22 & 0.0339 & --- & 0.64 \\
\hline & Crisphead & 7.95 & 0.0759 & -0.00014 & 0.79 \\
\hline
\end{tabular}

${ }^{2} \mathrm{Quadratic}$ has the form $\mathrm{Y}=\mathrm{A}+\mathrm{Bx}+\mathrm{Cx}^{2}$ and linear has the form $\mathrm{Y}=\mathrm{A}+\mathrm{Bx}$, where $\mathrm{Y}$ is total aboveground $\mathrm{P}$ (in kilograms per hectare); $\mathrm{x}$ is fertilizer rate (in kilogram per hectare); and A (intercept), B (linear coefficient), and $\mathrm{C}$ (quadratic coefficient) are constants obtained by fitting model to the data. crisphead lettuce, romaine and crisphead lettuce consistently accumulated more $P$ because of their larger biomass production (Table 5 and Fig. 2). Romaine and crisphead lettuce tended to accumulate more $\mathrm{P}$ than leaf, which, in turn, generally accumulated more $\mathrm{P}$ than Bibb and Boston.

Although differences in tissue $\mathrm{P}$ concentration among the lettuce types did not consistently explain the variability in $\mathrm{P}$ rates required for maximum yields, these differences might affect the values for critical tissue $\mathrm{P}$ concentration within each lettuce type (Tables 3 and 4). Because we collected leaf tissue data at the eight-leaf stage only in the Fall 1991 and the Winter 1991 experiments, we are not able to estimate critical leaf-P concentrations with confidence. However, as with the whole aboveground plant tissue at maturity, $\mathrm{P}$ concentrations in the leaf tissue at the eight-leaf stage were generally higher for leaf, Bibb, Boston, and romaine than for crisphead lettuce. Additional work to generate reliable critical $\mathrm{P}$ concentrations for lettuce types other than crisphead is needed.

Overall results from this study show the $\mathrm{P}$ rate $\times$ lettuce type interactions for most measured responses were strongly influenced by the performance of individual lettuce types within season. Similar results were observed in another study comparing the relative response of several crisphead cultivars to fertilizer P (Nagata et al., 1992). Because weather conditions in southern Florida during the fallwinter-spring period are not predictable, fertilizer recommendations should be based on long-term probability of response.

Averaging the data from all four experiments, mean $\mathrm{P}$ rates required for maximum yield on these low-P testing soils were (in $\mathrm{kg}$ P/ha) 148 for leaf, 142 for Bibb, 202 for Boston, 144 for romaine, and 147 for crisphead lettuce. Thus, with the exception of Boston, a similar average $\mathrm{P}$ rate was required for maximum yield of all lettuce types over all experiments. Furthermore, the relationship between relative yield and soil-test $\mathrm{P}$ across seasons (Table 6 and Fig. 3) showed that the estimated critical soil-test P level for leaf, Boston, romaine, and crisphead lettuce type were close to the $22 \mathrm{~g} \cdot \mathrm{m}^{-3}$ currently used to make $\mathrm{P}$ fertilizer recommendations for lettuce on Histosols in southern Florida. Although the calculated critical soil-test P level for Bibb lettuce appeared to be slightly higher, the data for Bibb were more variable (note the lower $r^{2}$ value), and the estimated critical soil-test $P$ index also is within error of the critical concentration currently used.

The results of these experiments were somewhat surprising because crisphead and romaine lettuce generally produce appreciably more biomass and accumulate more $\mathrm{P}$ than the leaf, Boston, and Bibb types. One might expect the latter lettuce types to consistently have a lower $\mathrm{P}$ requirement. However, Buso and Bliss (1988), using sand culture techniques, suggested that some butterhead types were actually less P efficient than other lettuce types under P-deficient regimes. These authors, however, found no differences among 

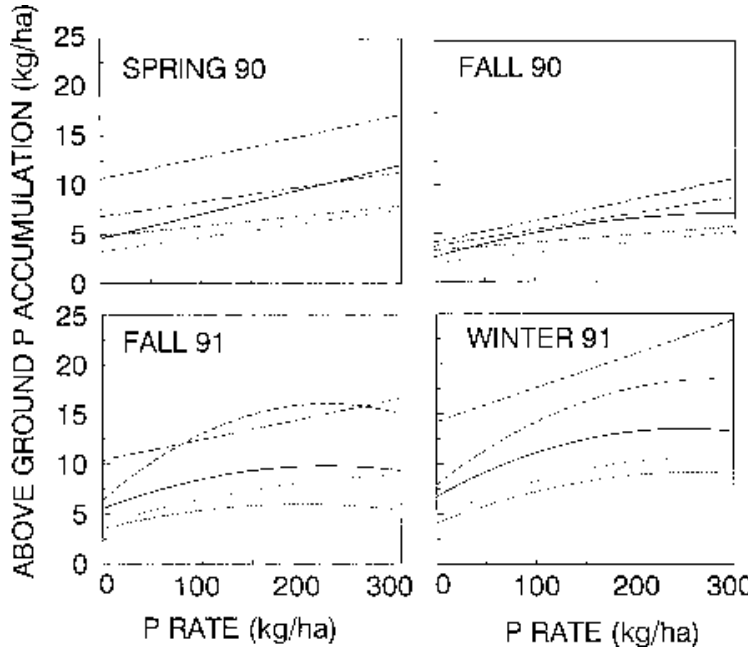

Fig. 2. Predicted $\mathrm{P}$ accumulation by five lettuce types during four cropping seasons. ( (--.---) Bibb, (.................) Boston, (------) Romaine, and (-..-..-........) crisphead.

Table 6. Equation parameters for relative yield of five lettuce types as influenced by soil-test P.

\begin{tabular}{|c|c|c|c|c|c|}
\hline \multirow{2}{*}{$\begin{array}{l}\text { Lettuce } \\
\text { type }\end{array}$} & \multicolumn{4}{|c|}{ Equation parameters $^{\mathrm{z}}$} & \multirow{2}{*}{$\begin{array}{l}\text { Critical soil } \\
\text { test P levels } \\
\left(\mathrm{g} \cdot \mathrm{m}^{-3}\right)\end{array}$} \\
\hline & A & $\mathrm{B}$ & $\mathrm{C}$ & $r^{2}$ & \\
\hline Leaf & 21.62 & 7.40 & -0.183 & 0.56 & 20.2 \\
\hline Bibb & 26.55 & 5.53 & -0.105 & 0.46 & 26.2 \\
\hline Boston & -26.17 & 10.87 & -0.234 & 0.83 & 23.2 \\
\hline Romaine & -4.34 & 9.88 & -0.245 & 0.60 & 20.2 \\
\hline Crisphead & -39.18 & 13.53 & -0.330 & 0.91 & 20.2 \\
\hline
\end{tabular}

${ }^{\mathrm{z}} \mathrm{Quadratic}$ response and plateau model has the form $\mathrm{Y}=\mathrm{A}+\mathrm{Bx}+\mathrm{Cx}^{2}$ if $\mathrm{x}<\mathrm{Cp}$ and $\mathrm{Y}=\mathrm{Yp}$ if $\mathrm{x} \geq \mathrm{Cp}$, where $\mathrm{Y}$ is relative yield and $\mathrm{x}$ is soil-test $\mathrm{P}$ (in grams per cubic meter); A (intercept), B (linear coefficient), C (quadratic coefficient), $\mathrm{Cp}$ (critical soil test $\mathrm{P}$ level that occurs at intersection of the quadratic response and the plateau lines), and Yp (plateau yield) are constants obtained by fitting model to the data.

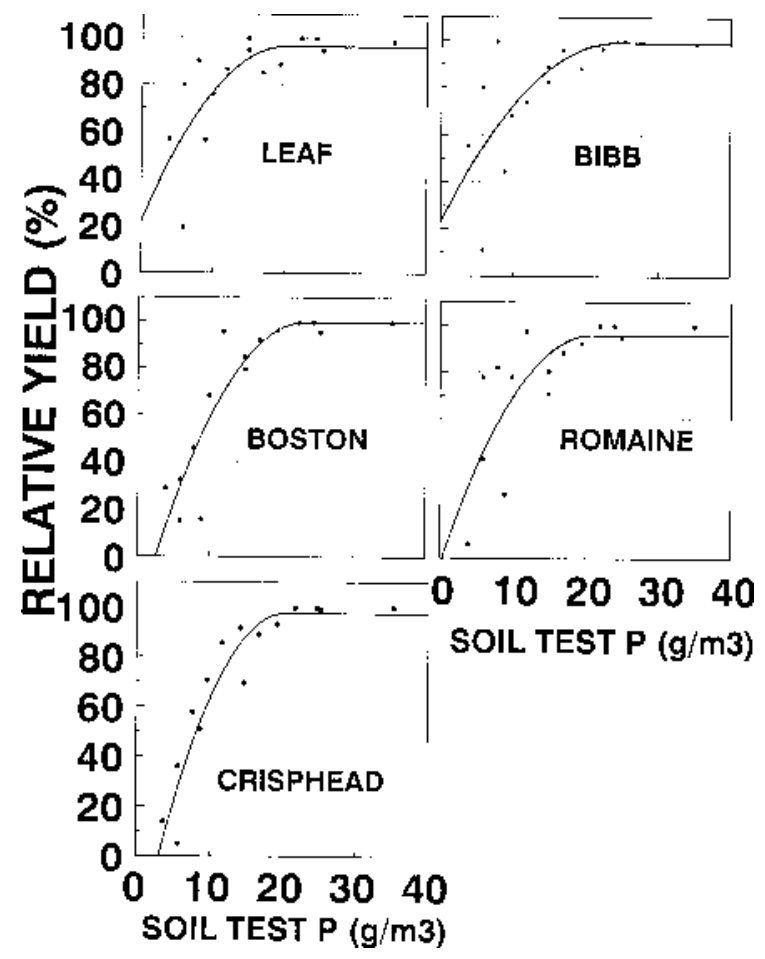

lettuce types under conditions of high $\mathrm{P}$ and found no differences in $\mathrm{P}$ efficiency among butterhead types grown in two geographic regions. They suggested that the lack of differences observed under conditions of high $\mathrm{P}$ may be because most lettuce cultivars are typically bred and grown under conditions of high fertility.

Results of this study provide a basis for concluding that various lettuce types should be fertilized similarly in respect to $P$ and suggest that current soil-test-based $\mathrm{P}$ fertilizer recommendations used for crisphead lettuce are generally adequate for other lettuce types grown.

\section{Literature Cited}

Alt, D. 1987. Influence of $\mathrm{P}$ and $\mathrm{K}$ fertilization on the yield of different vegetable species. J. Plant Nutr. 10:1429-1435.

Buso, G.S.C. and F.A. Bliss. 1988. Variability among lettuce cultivars grown at two levels of available phosphorus. Plant \& Soil 111:67-73.

Greenwood, D.J., T.J. Cleaver, M.K. Turner, J. Hunte, K.B. Niedorf, and S.M. Loquens. 1980. Comparisons of the effects of phosphate fertilizer on yield, phosphate content, and quality of 22 different vegetable and agricultural crops. J. Agr. Sci. (Camb.) 95:457-469.

Murphy, J. and J.P. Riley. 1962. A modified single solution method for the determination of phosphate in natural waters. Anal. Chem. Acta 27:3133.

Nagata, R.T., C.A. Sanchez, and F.J. Coale. 1992. Crisphead lettuce cultivar response to fertilizer phosphorus. J. Amer. Soc. Hort. Sci. 117:721724.

Sanchez, C.A. 1990. Soil testing and fertilization recommendations for crop production on organic soils in Florida. Univ. of Florida Agr. Bul. 876.

Sanchez, C.A., S. Swanson, and P.S. Porter. 1990. Relative efficiency of broadcast and banded $\mathrm{P}$ for lettuce. J. Amer. Soc. Hort. Sci. 117:721724.

Snyder, G.H. H.W. Burdine, J.R. Crocket, G.J. Gascho, D.S. Harrison, G. Kidder, J.W. Milshoe, D.L. Myhre, F.M. Pate, and S.F. Shih. 1978. Water table management for organic soil conservation and crop production in the Florida Everglades. Univ. of Florida Bul. 801.

SAS Institute. 1982. SAS user's guide: Statistics. 1982 ed. SAS Institute, Cary, N.C.

Wolf, B. 1982. A comprehensive system of leaf analysis and its use for diagnosing crop nutrient status. Commun. Soil Sci. Plant Anal. 13:10351059.

Fig. 3. Relative yield of five lettuce types as influenced by soil test $P$. 